\title{
Effectiveness of mobilization practices for patients with neck pain due to myofascial pain syndrome: a randomized clinical trial
}

\author{
Miyofasiyal ağrı sendromuna bağlı boyun ağrılı hastalarda mobilizasyon uygulamalarının etkinliği: \\ Randomize bir klinik çalışma
}

Adem Ylldırım, ${ }^{1}$ Abuzer Akbaş, ${ }^{2}$ Gülseren Dost Sürücü, ${ }^{1}$ Mehmet Karabiber, ${ }^{1}$ Dilay Eken Gedik, ${ }^{3}$ Semra Aktürk ${ }^{3}$

${ }^{1}$ Department of Physical Medicine and Rehabilitation, Medical Faculty of Adiyaman University, Adıyaman, Turkey

${ }^{2}$ Department of Physical Medicine and Rehabilitation, Physical Therapy and Rehabilitation Unit, Adiyaman University, Adiyaman, Turkey

${ }^{3}$ Physical Medicine and Rehabilitation, Adıyaman Training and Research Hospital, Adıyaman, Turkey

Received / Geliş tarihi: September 2015 Accepted / Kabul tarihi: January 2016

\begin{abstract}
Objectives: This study aims to investigate the effects of the mobilization applications on neck pain caused by myofascial pain syndrome (MPS).

Patients and methods: Between November 2014 and May 2015, a total of 60 patients diagnosed with MPS at our clinic were included in this study and randomly divided into two groups. Ten sessions of hot pack, therapeutic ultrasound and TENS were performed for group 1 while five additional sessions of (on alternate days) manual therapy (scapular mobilization and Cyriax mobilization) were performed for group 2. Visual analog scale (VAS) was used to evaluate head and neck pain. Results and mean values of local tenderness scores were recorded by using an algometer for six points at each side of the cervical region and trapezius muscles. Furthermore, neck disability scores, endurance of deep cervical flexor muscles and state and trait anxiety scores were recorded. All assessments were performed four times in total: at the beginning of the treatment, at the end of the treatment, in the second week and in the third month after the treatment.

Results: In group 1, decreases in almost none of the VAS scores of head and neck pain were significant in the post-treatment period. Local tenderness scores of neck were significant in the second week and the third month after the treatment. Endurance measurement values were significant in the second week after the treatment. Decrease in the neck disability index scores was found significant at all three measurements of the post-treatment period. In group 2, decreases in head and neck pain scores and neck disability scores were all found significant in the evaluations of the post-treatment period. Similarly, we found significant improvements in almost all of the local tenderness scores of neck and trapezius muscles and endurance measurement values (except for trapezius tenderness measurement in the second week and endurance measurement in the third month). In addition, state anxiety scores in early period were also significant in this group.

Conclusion: This study demonstrated that cervical and scapular mobilization practices have positive effects on pain scores of head, state anxiety levels and neck disability scores (due to improvements in local tenderness, pain scores and endurance of cervical muscles) when added to standard treatment of patients with MPS.
\end{abstract}

Keywords: Manual therapy; myofascial pain syndrome; neck pain.

$\ddot{O} Z$

Amaç: Bu çalışmada miyofasiyal ağrı sendromuna (MAS) bağlı boyun ağrılı hastaların tedavisinde mobilizasyon uygulamalarının etkinliği araştırıldı.

Hastalar ve yöntemler: Kasım 2014 - Mayıs 2015 tarihleri arasında kliniğimizde MAS tanısı konulan 60 hasta çalısmaya dahil edildi ve randomize olarak iki gruba ayrıld. Grup 1'deki hastalara 10 seans hot pack, terapötik ultrason ve TENS uygulanırken, grup 2'deki hastalara ek olarak beş seans (günaşırı) manuel tedavi (skapular mobilizasyon ve Cyriax mobilizasyon yöntemleri) uygulandı. Baş ve boyun ağrı değerlendirmesi için görsel analog ölçeği (GAÖ) kullanıldı. Algometre ile servikal bölgede ve trapez kasında her bir taraf için altışar noktanın lokal hassasiyet ölçümü sonuçları ve ortalamaları kaydedildi. Ayrıca boyun özür değerlendirme skorları, servikal derin fleksör kasların endurans ölçüm sonuçları ve durumluk ve sürekli kaygı skorları kaydedildi. Tüm değerlendirmeler tedavi başlangıcında, tedavi bitiminde, tedavi sonrası ikinci hafta ve üçüncü ayda olmak üzere toplam dört kez tekrarlandı.

Bulgular: Grup l'de, tedavi sonrası dönemde, baş ve boyun ağrı GAÖ skorlarındaki düşüşlerin hemen hiçbiri anlamlı değildi. Boyun lokal kas hassasiyet skorları tedavi sonrası ikinci hafta ve üçüncü ayda anlamlıydı. Endurans ölçüm değerleri tedavi sonrası ikinci haftada anlamlıydı. Boyun disabilite indeks skorundaki düşüs tedavi sonrası dönemde yapılan üç değerlendirmede de anlamlı bulundu. Grup 2'de ise baş ve boyun ağrıları ve boyun disabilite skorlarındaki düșüşler tedavi sonrası tüm değerlendirmelerde anlamlı bulundu. Benzer şekilde, boyun ve trapez kasların lokal hassasiyet skorları ve endurans ölçümlerinin hemen tamamında (ikinci hafta trapez hassasiyet ölçümü ve üçüncü ay endurans ölçümü hariç) anlamlı düzelmeler saptandı. Ek olarak, bu grupta durumluk kaygı skoru da erken dönemde anlamlı idi. Sonuç: Bu çalışma, MAS’nin standart tedavisine eklenen servikal ve skapular mobilizasyon uygulamalarının, baş ağrıları, durumluk kaygı düzeyleri ve (servikal kasların lokal hassasiyet, ağrı ve endurans skorlarında iyileşmeler nedeniyle) boyun disabilite skorları üzerine olumlu etkileri olduğunu göstermiştir.

Anabtar sözcükler: Manuel terapi; miyofasiyal ağrı sendromu; boyun ağrısı.

Corresponding author / İletişim adresi: Adem Yıldırım, MD. Adıyaman Üniversitesi Tıp Fakültesi, Fiziksel Tıp ve Rehabilitasyon Anabilim Dalı, 02040 Adıyaman, Turkey. e-mail / e-posta: ademyildirim@yahoo.com

Cite this article as:

Yıldırım A, Akbaş A, Dost Sürücü G, Karabiber M, Eken Gedik D, Aktürk S. Effectiveness of mobilization practices for patients with neck pain due to myofascial pain syndrome: a randomized clinical trial. Turk J Phys Med Rehab 2016;62(4):337-45 
Myofascial pain syndrome (MPS) is a regional pain syndrome characterized by taut bands inside muscles or myofascial structures which are known as trigger points and sensory (hyperalgesia, dysesthesia, hypersensitivity, referred pain), motor (local twitching response, muscle spasm, decreased muscular coordination and weakness, limitations of joint movements) and autonomic (changes in skin temperature, erythema, piloerection, diaphoresis, salivation, lacrimation, proprioceptive disturbances) symptoms when these points are stimulated. ${ }^{[1,2]}$ Its etiology is not known exactly. Postural or ergonomic disturbances, overuse of the muscles or mechanical causes like recurrent micro traumas, hormonal disturbances, vitamin and mineral imbalances and stress may cause a predisposition to this disease. Although reports about incidences and prevalence of MPS vary widely in the literature, prevalence in the population is reported to be approximately $12 \%$ and MPS is found in $30-50 \%$ of patients who present with pain originating from musculoskeletal system. ${ }^{[3,4]}$ In addition, it is seen mostly in the fourth and fifth decades of life and it is twice as common in females. ${ }^{[5]}$ In a study, $54.6 \%$ of head and neck pain was found to be related to myofascial pain, and another study found myofascial pain in 55\% of 164 patients presenting with chronic head and neck pain. ${ }^{[6,7]}$

The primary goal of MPS treatment can be summarized as relieving pain, improving range of motion of joints and removing predisposing factors for each trigger point. In clinical practice, many noninvasive treatment options such as patient education, management of predisposing factors, medical treatments (analgesics, muscle relaxants, antidepressants, etc.), superficial and deep heaters [hotpack (HP), therapeutic ultrasound (US), etc.], cold spray, electrotherapy [transcutaneous electrical nerve stimulation (TENS), Interferential current therapy, etc.], low energy light amplification by stimulated emission of radiation (LASER), extracorporeal shock wave therapy (ESWT), manual therapy practices, therapeutic massage, ischemic compression, stretching and relaxation exercises and invasive treatment options such as trigger point injections (dry needling) and acupuncture can be used. ${ }^{[8]}$ Monotherapy is frequently inadequate to cause healing. When multiple treatments are applied, performing high quality research that will contribute to evidence based treatment is difficult due to an inability to standardize parameters such as treatment dosage and time and technical difficulties to design control groups that will use sham therapies.
Manual therapy can be defined as applications performed by hand to restore painless normal range of motion of vertebra and extremities and to relieve muscular tension in order to achieve functionality. Clinical research regarding spinal manipulations for neck pain has been increasing since 1980's. Cashley ${ }^{[9]}$ stated that more than 50 methods are used just for manipulations in the cervical region but a good biomechanical and neurological knowledge is required. Although many methods of manual therapy have been defined, these can be classified as manipulation (thrust mobilization), non-thrust mobilization and soft tissue techniques. Manipulation involves high velocity and low amplitude thrusts and it requires high level of attention and skill due to potential risks and complications. Therefore, it should be performed by experienced specialists who are familiar with indications and definite and relative contraindications. Non-thrust mobilization which is a safer technique depends on sliding of joints and or involving low velocity and high amplitude moves that are applied repeatedly.

Research on manual therapy for cervical region is primarily about non-specific neck pains using manipulation techniques. Unfortunately, few studies examined effects of manipulation for MPS which is known to be an important cause of head-neck pains. ${ }^{[10,11]}$ Studies examining mobilization techniques without thrust in patients with MPS are scarce, so it is difficult to obtain evidence based data in this patient group. More clinical studies are still needed to examine the effectiveness of these techniques.

The purpose of this randomized clinical study was to demonstrate the effects of non-thrust mobilization applications (such as scapular mobilization and Cyriax mobilization) using measurement of trigger point sensitivity, neck and head pain values, endurance of deep cervical flexor muscles, level of neck disability and anxiety.

\section{PATIENTS AND METHODS}

Sixty patients, between 18 and 45 years of age, came to our outpatient clinics with complaints of neck and upper back pain and were diagnosed as having MPS with only one active trigger point in either trapezius or levator scapulae muscles according to the Travell-Simons criteria $^{[12,13]}$ were included in the study. This study was approved by Ethics Committee of Adiyaman University with an approval number of 2014-08-02. Written informed consent was taken from patients who accepted to join this study. The 
study was conducted in accordance with the principles of the Declaration of Helsinki. Patients who had pathology in cervical vertebra or discs revealed by cervical vertebra magnetic resonance imaging, history of trauma or operation affecting cervical region, diagnosis of torticollis, scoliosis, a known neurological disease, secondary osteoporosis, rheumatologic or systemic diseases (hypertension, active infection, chronic obstructive pulmonary disease, carcinoma, etc.) or who were pregnant were excluded. The patients were divided into two equal groups using the block randomization system using Random Allocation Software $2.0^{\mathrm{TM}}$.

Patients in group $1(\mathrm{n}=30)$ received standard MPS treatment in our clinic which consisted of hotpack (HP), conventional TENS and therapeutic ultrasound (10 sessions in 5 days). Hotpack and conventional TENS (BTL-4000TM ultrasound with combined electrotherapy device at $100 \mathrm{~Hz}$ frequency, 60-100 A amplitude, with $4 \times 6 \mathrm{~cm}$ electrodes) were applied to the cervical paravertebral region and upper and middle trapezius for 20 minutes and therapeutic ultrasound (BTL-4000TM ultrasound and combined electrotherapy device, $1 \mathrm{~W} / \mathrm{cm}^{2}, 1 \mathrm{MHz}$ ) was applied bilaterally for eight minutes.

Patients in group $2(n=30)$ received the same standard treatment as group 1 in addition to five sessions of (on alternate days) manual therapy (scapular mobilization and Cyriax mobilization).

Scapular mobilization: The patient lay on the examination table at lateral recumbent position with knees at $45^{\circ}$ flexion. The therapist located his left hand at inferior scapula and right hand at superior scapula. In this position, mediolateral, superoinferior and rotatory movements were applied to the scapula. Moreover, the hand located at inferior scapula was moved from inferior border internally and distraction towards the opposite side was applied. Ten sets of these movements were repeated 10 times with 30 seconds intervals between sets. ${ }^{[14]}$

Cyriax mobilization techniques: The patient lay supine with knees at $45^{\circ}$ flexion and the therapist applied deep friction massage to cervical paravertebral muscles and nuchal ligament in this position. Then a vertebrobasillar artery insufficiency test was performed to measure appropriateness of cervical region mobilization. Then, twice traction, three times traction with rotation and anteroposterior sliding techniques were applied to patients whose test results were negative. ${ }^{[15]}$
Pain assessment: Visual analog scale (VAS) was used to assess head and neck pain. For VAS assessment, the meaning of numbers from $0-10$ (0 means no pain and 10 means most severe pain) which were located on a $100 \mathrm{~mm}$ line was told to the patients. Values marked by the patients for neck pain were recorded as VAS neckpain; values for head pain were recorded as VAS $S_{\text {headpain. }}$

Assessment of muscle tenderness (Algometric measures): Sensitivities of upper trapezius and cervical paravertebral muscles (pain thresholds) were measured with a commander algometer (JTECH Medical, Midvale, UT, USA). We used the protocol which Walton et al. ${ }^{[16]}$ described for clinical pressure pain threshold testing of upper fibers of the trapezius muscle in people with acute neck pain. Due to the plurality and widespread locations of trigger points in most of the patients, we identified 12 reference points ( 6 points for right side and 6 for left). The three points including medial acromion, muscle belly and at the level of $7^{\text {th }}$ vertebra were assessed for trapezius muscle sensitivity and three points including $\mathrm{C} 1$ level, between C3-4 and C7 level were assessed for cervical paravertebral muscle sensitivity. While pressure was being applied to the defined points at the moment when the patient perceived pain, the algometer was removed from the body and the value appearing on the display was recorded as pressure force $\left(\right.$ Newton $\left./ \mathrm{cm}^{2}\right)$. Three measurements were recorded from each point and all assessments were performed for right and left sides separately. As a result, we had 18 measurements for cervical paravertebral muscles and 18 measurements for trapezius muscles for each patient. In order to facilitate statistical analysis, we described two average values for 36 measurements of each patient. Arithmetic mean of 18 measurements from bilateral cervical paravertebral muscles was described as the global cervical local sensitivity (GCLS) score and arithmetic mean of 18 measurements from trapezius muscles was described as the global trapezius local sensitivity (GTLS) score. All measurements were performed by the same specialist with the same algometer.

Assessment of deep cervical flexor muscle endurance: The patients lay on the examination table in hook position with their knees at $45^{\circ}$ flexion. In this position they were asked to retract their heads by moving their chins to slightly posterior. The therapist located his thumb and index finger below the protuberantia occipitalis and asked the patient to elevate his head until it no longer touched the therapist's fingers. When the patient felt overwhelming pain, the head lost retraction position or the head made flexion so that occiput moved far away from fingers meaning that superficial 
cervical muscles such as sternocleidomastoid and anterior scalene muscles became active the testing procedure was accepted as terminated. Test duration was recorded in seconds. ${ }^{[17]}$

Assessment of neck disability: Vernon Mior Neck Disability Index (VMNDI) which was developed by Vernon and Mior was used to evaluate neck disability. ${ }^{[18]}$ This test includes 10 items (each item gets $0-5$ points so the maximum score is 50 ); four items question subjective symptoms (headache, severity of pain, concentration, sleep) and six items question activities of daily living (grooming, weightlifting, reading, work/ professional life, driving, and recreation). Validity and reliability of Turkish version of this scale was performed by Aslan et al. ${ }^{[19]}$ in 2008 .

Assessment of anxiety level: State-Trait Anxiety Inventory (STAI) was used to measure anxiety level of patients. This self-report questionnaire which assesses state anxiety (STAI-I) and trait anxiety (STAI-II) with 20 item subscales was developed by Spielberger ${ }^{[20]}$ and validity and reliability of its Turkish version studied by Öner and Le-Compte. ${ }^{[21]}$ STAI-I, evaluates how a person feels and what his anxiety level is at the time and conditions of evaluation. STAI-II evaluates how a person feels and what is his anxiety level in general regardless of current conditions. Items in each questionnaire are scored from 1-4, so possible scores of each subscales ranged from 20 to 80 .

All assessments were performed at the beginning of treatment and repeated at the end of treatment, two weeks and three months after the treatment. Early post-treatment and control values of each group were compared with pretreatment values.

\section{Statistical analysis}

The official link of the department of statistics of The University of British Columbia using "Hypothesis Testing: Two-Sample Inference - Estimation of Sample
Size and Power for Comparing Two Means in Bernard Rosner's Fundamentals of Biostatistics" was used to estimate the sample size of the study groups. (Link: http://www.stat.ubc.ca/ rollin/stats/ssize/n2.html) Continuous variables with normal distribution were shown as mean \pm standard deviation. Categorical variables were shown as numbers. The sample size was calculated to be minimum 16 participants for each group according to the following parameters: mean $\mathrm{VAS}_{\text {neckpain }}$ at baseline and after treatment were estimated to be 5.60 and 3.27 respectively; sigma (common standard deviation): 1.5; alpha (type I error rate): 0.05; value for desired power: 0.99 which were obtained from a similar randomized clinical trial ${ }^{[22]}$

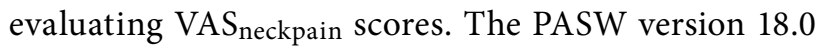
(SPSS Inc., Chicago, IL, USA) program was used for statistical analyses. The 'Shapiro-Wilk's test' was used to test normal distribution assumption of groups. The 'Pearson chi-square test' was used to compare the gender and 't-test for equality of means' was used to compare parameters including age, height and weight of groups. Repeated Measures ANOVA test was used for comparisons of post-treatment (immediate, $2^{\text {nd }}$ week and $3^{\text {rd }}$ month) vs. pre-treatment data for each group as well as interactions between groups and time. The 'Greenhouse-Geisser correction' method was used when sphericity assumption was violated for repeated measures ANOVA. Furthermore, the reliability value (Cronbach's Alpha value) of the VMNDI and STAI scales were calculated separately per study group and were 0.901 and 0.925 respectively. A $p$ value $<0.05$ was considered to indicate statistical significance.

\section{RESULTS}

There was no statistically significant difference between groups in terms of demographic data. The female to male ratio of group 1 and 2 were 3.3 and 2.8 respectively. The mean age, height and weight of group 1 were 32.3 years, $165.2 \mathrm{~cm}$ and $70.6 \mathrm{~kg}$, while they were

Table 1. Demographic features and the test of normality of groups

\begin{tabular}{|c|c|c|c|c|c|c|c|}
\hline & \multicolumn{3}{|c|}{ Group 1} & \multicolumn{3}{|c|}{ Group 2} & \multirow[b]{2}{*}{$p \dagger \ddagger$} \\
\hline & $\mathrm{n}$ & Mean \pm SD & $p^{*}$ & $\mathrm{n}$ & Mean \pm SD & $p^{*}$ & \\
\hline Age (years) & & $32.3 \pm 7.0$ & 0.098 & & $33.0 \pm 6.3$ & 0.911 & $0.671 \ddagger$ \\
\hline Gender & & & & & & & $0.766 \dagger$ \\
\hline Male & 7 & & & 8 & & & \\
\hline Female & 23 & & & 22 & & & \\
\hline Height (cm) & & $165.2 \pm 8.8$ & 0.359 & & $166.9 \pm 8.2$ & 0.519 & $0.425 \ddagger$ \\
\hline Weight (kg) & & $70.6 \pm 11.8$ & 0.199 & & $68.3 \pm 9.4$ & 0.426 & $0.408 \ddagger$ \\
\hline
\end{tabular}


33.0 years, $166.9 \mathrm{~cm}$ and $68.3 \mathrm{~kg}$ for group 2. The demographic features of the groups were summarized in Table 1. In group 1, decreases in VAS headpain and VAS $_{\text {neckpain }}$ were almost not significant statistically (except $\mathrm{VAS}_{\text {neckpain }}$ scores at third month) in the post-treatment period. Increase in GCLS (decreased sensitivity) were significant in the second week and third month after treatment. Increase in GTLS scores (decreased sensitivity) were not significant either immediately after treatment or late post-treatment period. Increase in endurance duration values of deep cervical flexor muscles were significant only in second week. Decreases in VMNDI scores were significant at all three measurements of post-treatment period. The changes in STAI I and II scores were not significant in this group (Table 2).

In group 2, decreases in VAS $S_{\text {headpain }}$ and $\mathrm{VAS}_{\text {neckpain }}$ scores and VMNDI scores were all significant in early and late period of treatment. Similarly, increases in GCLS and GTLS values and endurance duration values of deep cervical flexor muscles were almost (except
GTLS in $2^{\text {nd }}$ week and endurance measure at $3^{\text {rd }}$ month) statistically significant. In addition, STAI-I scores in early period were also significant in this group. Changes in STAI-II scores were also not significant in this group (Table 2).

According to the statistical analysis of group and time interactions, there were significant differences (improvements in VAS neckpain, GCLS, GTLS and endurance duration values of deep cervical flexor muscles) between groups in time periods of before treatment vs. immediate post-treatment scores. The interactions between groups and time were summarized in Table 3. The changes (\% difference) of all parameters were summarized in Figure 1.

\section{DISCUSSION}

The main treatment purpose of MPS is to eliminate painful trigger points, relieve local muscle spasms and in the end to break the vicious 'spasm-painspasm' circle. Superficial heating agents (HP, infrared) are widely used to relieve pain and local muscle

Table 2. Comparisons of before treatment vs. after treatment (repeated measures) scores of each group

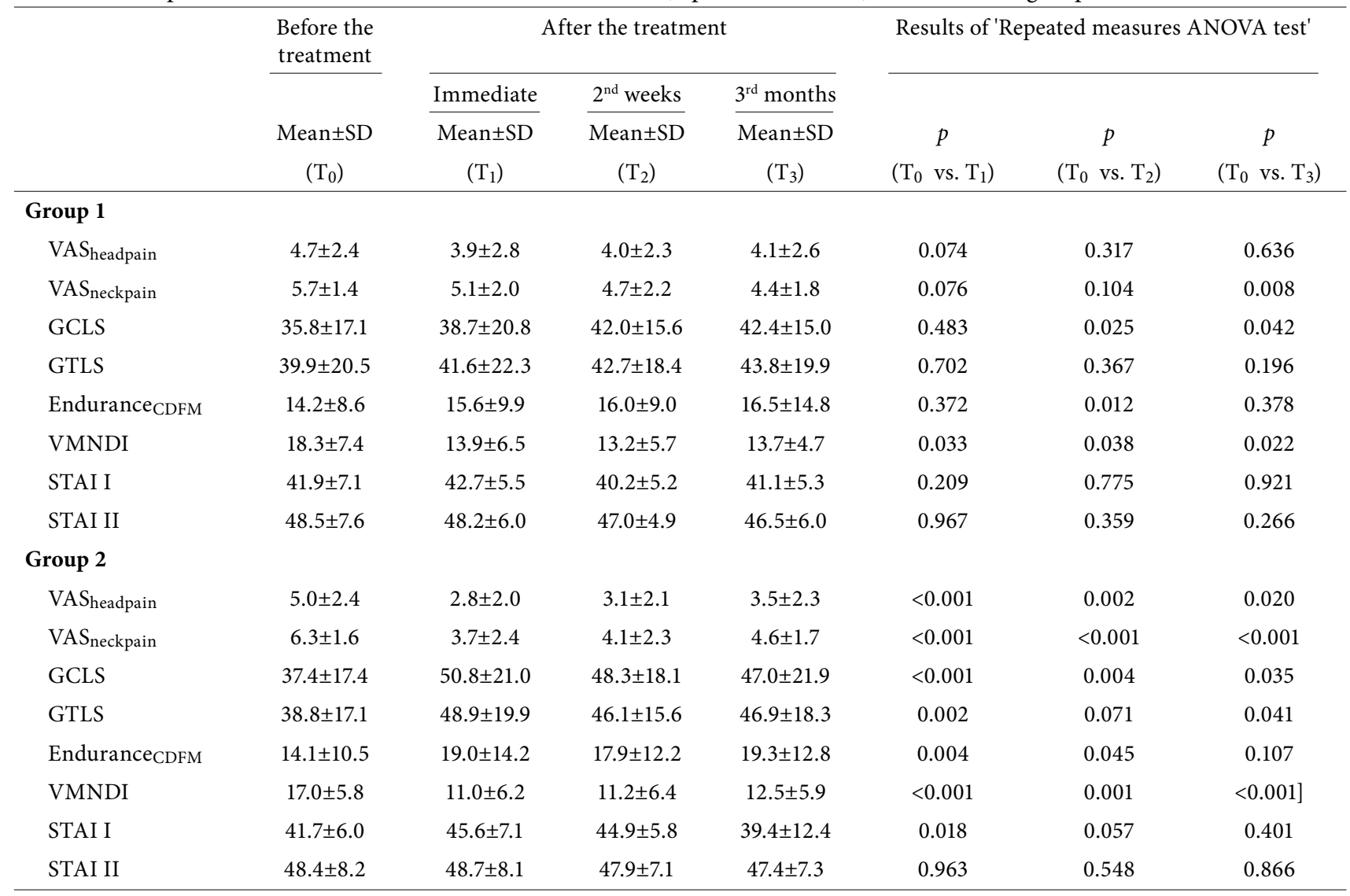

SD: Standard deviation; $\mathrm{T}_{0-3}$ : time periods of measurements; VAS: Visual analog scale; GCLS: Global cervical local sensitivity score; GTLS: Global trapezius local sensitivity score; CDFM: Cervical deep flexor muscles; VMNDI: Vernon-Mior Neck Disability Index; STAI: State-Trait Anxiety Inventory. 
Table 3. Comparison of groups for before and after treatment (three measures) means and interactions between groups and time

\begin{tabular}{lcccc}
\hline Parameter & \multicolumn{3}{c}{ Results of 'Repeated measures ANOVA test' (interactions between groups and time) } \\
\cline { 2 - 4 } & $p^{*}$ & $p^{\dagger}$ & $p \ddagger$ & $p \S$ \\
\hline VAS $_{\text {headpain }}$ & 0.587 & 0.067 & 0.119 & 0.148 \\
VAS $_{\text {neckpain }}$ & 0.793 & 0.014 & 0.098 & 0.454 \\
GCLS & 0.185 & 0.002 & 0.517 & 0.699 \\
GTLS & 0.482 & 0.006 & 0.514 & 0.345 \\
Endurance & 0.427 & 0.041 & 0.653 & 0.599 \\
VMNDI & 0.622 & 0.104 & 0.390 & 0.177 \\
STAI I & 0.169 & 0.343 & 0.093 & 0.846 \\
STAI II & 0.956 & 0.900 & 0.932 & 0.470 \\
\hline
\end{tabular}

VAS: Visual analog scale; GCLS: Global cervical local sensitivity score; GTLS: Global trapezius local sensitivity score; CDFM: Cervical deep flexor muscles; VMNDI: Vernon-Mior Neck Disability Index; STAI: State-Trait Anxiety Inventory; ${ }^{\star} P$ values summarized from “Tests of Between-Subjects Effects" table); $\dagger$,,$\S P$ values summarized from "Tests of Within-Subjects Contrasts" table ( $\dagger$ Before treatment vs. immediate after treatment; $¥$ Before treatment vs. $2^{\text {nd }}$ week; $₫$ Before treatment vs. $3^{\text {rd }}$ month).

spasms due to active trigger points, to increase ROM and to induce sedation. ${ }^{[23]}$ Therapeutic US is another therapeutic agent which is commonly used in physiotherapy for MPS patients. Because therapeutic US increases viscoelasticity by its deep heating effect, has vasodilator effect and increases metabolism, it has been reported to be beneficial in $\mathrm{MPS}^{[8,24]}$ at low $\left(0.520 \mathrm{~W} / \mathrm{cm}^{2}\right),{ }^{[25]}$ medium $\left(0.8-1.5 \mathrm{~W} / \mathrm{cm}^{2}\right)^{[24,26]}$ and high doses $\left(1.5-3 \mathrm{~W} / \mathrm{cm}^{2}\right) .{ }^{[27,28]}$ In a recent study by Koca et al., ${ }^{[29]}$ all therapeutic US doses were found to be effective for MPS patients although high dose was more effective than moderate and low doses. In another recent randomized controlled study, Ilter et al. ${ }^{[30]}$ used continuous, intermittent or sham US and found that continuous US was superior to relieve pain at rest. Another agent commonly used in MPS physiotherapy is TENS. Transcutaneous electrical nerve stimulation is widely used in musculoskeletal disorders due to such effects as: stimulating release of beta-endorphins and enkephalins, it can stimulate gate-control mechanisms and sensory nerves, it has local vasodilation effects and it can relieve pain by stimulating acupuncture points. A study about effectiveness of TENS in MPS demonstrated that intensive TENS could decrease pain scores in the short term but no difference could be found in local sensitivities of trigger points. ${ }^{[31]}$ In another placebo controlled study about latent trigger points, TENS was found to be superior only

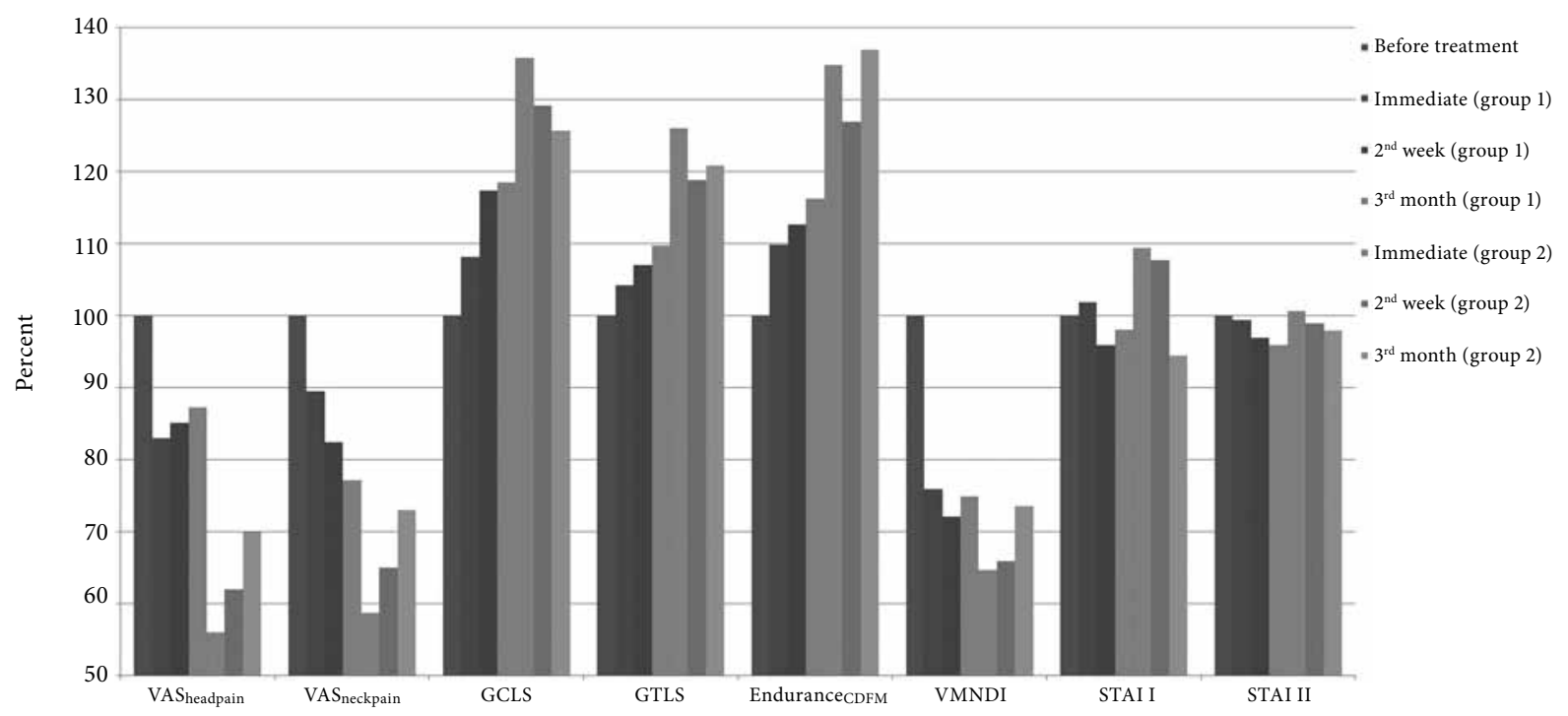

Figure 1. Percentage changes in the clinical parameters of the groups at time periods.

VAS: Visual analog scale; GCLS: Global cervical local sensitivity score; GTLS: Global trapezius local sensitivity score; CDFM: Cervical deep flexor muscles; VMNDI: Vernon-Mior Neck Disability Index; STAI: State-Trait Anxiety Inventory. 
in decreasing pain scores. ${ }^{[32]}$ A study which compared TENS + exercise with infrared reported that TENS + exercise was more effective for pain and disability at six months post-treatment. ${ }^{[33]}$ Frequently more than one treatment agent and exercise are used together and studies on this subject frequently assess effectiveness of combined treatments. A study by Esenyel et al. ${ }^{[34]}$ involving 102 patients with trigger points at trapezius muscle reported that both stretching exercises + ultrasound group and stretching exercises + trigger point injection group had significantly higher decrease in pain intensity, increase in pain threshold and range of motion than only exercise group. In addition, they could not find a significant difference between injection and ultrasound groups. Unfortunately, highquality studies that can demonstrate the short and long-term effectiveness of each treatment procedure separately (method, dosage, time period, etc.) are inadequate. In our clinic, standard treatments of patients with painful myofascial pain syndrome include application of HP, conventional TENS and therapeutic US. Unfortunately, according to present study results, including combined therapy mentioned above, we saw significant improvement only in a small number of certain parameters and measurements. Decreased sensitivity of cervical paravertebral muscles and improvements in endurance duration values of deep cervical flexor muscles at second week were considerable in addition to neck disability scores of all post-treatment period.

Although activation of both peripheral (decrease in chemical algogenic mediators, activation of segmental inhibitor pathways) and central inhibitor mechanisms have been suggested regarding the neurophysiological mechanisms of manual therapy, reflex inhibition and sympathetic stimulation theories are worth considering. Pikula ${ }^{[35]}$ applied manipulative treatment in patients with unilateral neck pain and found that reflex inhibition occurs due to mechanical stimulation of proprioceptors inside the joint capsule and muscle spindles and this leads to decreased pain, relaxation of muscles and increased segmental mobility. Chiu and Wright ${ }^{[36]}$ evaluated the relationship between cervical mobilization methods and sympathetic system and found that sympathetic stimulation has roles in cervical pain and mobility. A large number of studies have investigated manual therapy methods for neck pains, but these studies usually include patients with nonspecific neck pain originating from vertebral column and probable neurological and vascular complications. Di Fabio ${ }^{[37]}$ highlighted subclinical degenerative lesions at arterial walls after high velocity manipulations with thrust and therefore he suggested avoiding high velocity manipulative interventions with thrust and recommended using low velocity mobilization methods. We did not apply manipulations in this study due to potential neurologic and vascular risks and we aimed to minimize the risk of possible subclinical vascular degenerative lesions by involving patients between 18-45 years of age. Fortunately, no vascular or neurological complications occurred during the treatment and follow-up period in the present study. The main purpose of this study was to demonstrate possible effectiveness of scapular mobilization and Cyriax mobilization techniques for MPS patients. To the best of our knowledge, this is the first study demonstrating the effectiveness of these two techniques for MPS patients and we believe that our study will make such a contribution to the literature.

Although some studies have demonstrated that manual therapy may be superior to physical therapy for neck pain in acute and sub-acute periods their superiority in the late period has not previously been shown. In one of two studies by Hoving et al. ${ }^{[38]}$ mobilization methods were performed for 183 patients with nonspecific neck pain once a week for six weeks. During the acute period (at $7^{\text {th }}$ week), they found a higher success rate in intervention group than physical therapy group (exercise therapies twice a week) and medical treatment + patient education group. In their second study, they reported one year follow-up results and stated that the difference between groups was not statistically significant. ${ }^{[39]}$ In these studies, the intervention group consisted of patients with nonspecific neck pain and the causes of head and neck pains were not evaluated in detail. Like patients with nonspecific neck pain, our study demonstrated that mobilization techniques were more effective during the acute period in patients with MPS. In contrast to the literature, we found that mobilization techniques were superior in the late period (after 3 months) according to VAS headpain and endurance scores. Additionally, the results of this study showed that mobilization techniques were effective for headache in both acute and late periods, while standard physical therapy methods were not effective. We believe that, mechanical stimulation of proprioceptors in muscle spindles by mobilization cause relaxation of cervical muscles with reflex inhibitory effect and this relaxation can explain relief of tension type headache in this group.

Another point of investigation in this study was the effectiveness of these treatments on the anxiety level of patients. Current research showed that psychological 
status is closely related with pain. Poor psychological status can decrease pain threshold and chronic pain may impair psychological status. ${ }^{[40,41]}$ The results of this study suggest that mobilization therapies are effective on state anxiety during early periods but not in late period. We believe that improvements in the early period in such parameters might be caused from significant decreases in head and neck pains.

Limitations of our study include the relatively low number of patients, absence of long-term (1 year) follow-up results and lack of a sham manual therapy group due to technical difficulties.

In conclusion, this study demonstrated that cervical and scapular mobilization practices have positive effects on pain scores head of neck as well as local tenderness scores and endurance of cervical muscles. In addition, these applications may improve neck disability and state anxiety scores of patients with MPS.

\section{Declaration of conflicting interests}

The authors declared no conflicts of interest with respect to the authorship and/or publication of this article.

\section{Funding}

The authors received no financial support for the research and/or authorship of this article.

\section{REFERENCES}

1. Simons DG. New views of myofascial trigger points: etiology and diagnosis. Arch Phys Med Rehabil 2008;89:157-9.

2. Koca İ, Boyacı A. A new insight into the management of myofascial pain syndrome. Gaziantep Medical Journal 2014;20:107-12.

3. Borg-Stein J, Simons DG. Focused review: myofascial pain. Arch Phys Med Rehabil 2002;83:40-7.

4. Aydın R, Şen N, Ellialtıoğlu A. Eklem dışı romatizmal hastalıklar. Fiziksel Tip ve Rehabilitasyon. İstanbul: Nobel Tip Kitabevi; 2000. s. 299-320.

5. Başak A, Yılmaz ÖT. Servikal miyofasyal ağrı sendromunda fizyoterapinin ağrı, mental durum ve yaşam kalitesi üzerine etkisi. Fizyoterapi Rehabilitasyon 2012;23:73-82.

6. Hubbard JE. Myofascial trigger points. What physicians should know about these neurological imitators. Minn Med 2010;93:42-5.

7. Yap EC. Myofascial pain--an overview. Ann Acad Med Singapore 2007;36:43-8.

8. Auleciems LM. Myofascial pain syndrome: a multidisciplinary approach. Nurse Pract 1995;20:18.

9. Cashley M. Neurological complications of cervical spine manipulation. J R Soc Med 2001;94:314.

10. Vernon HT, Aker P, Burns S, Viljakaanen S, Short L. Pressure pain threshold evaluation of the effect of spinal manipulation in the treatment of chronic neck pain: a pilot study. J Manipulative Physiol Ther 1990;13:13-6.
11. Ruiz-Sáez M, Fernández-de-las-Peñas C, Blanco $C R$, Martínez-Segura R, García-León R. Changes in pressure pain sensitivity in latent myofascial trigger points in the upper trapezius muscle after a cervical spine manipulation in pain-free subjects. J Manipulative Physiol Ther 2007;30:578-83.

12. Simons DG, Travell JG, Simons LS. Travell \& Simons' Myofascial Pain and Dysfunction: The Trigger Point Manual. Vol. 1. Baltimore: Upper Half of Body. 2nd ed. Williams \& Wilkins; 1999. p. 1038.

13. Gerwin RD. Myofascial pain syndrome. In: Mense S, Gerwin RD, editors. Muscle pain: Diagnosis and Treatment. Berlin Heidelberg: Springer-Verlag; 2010. p. 15-83.

14. Surenkok O, Aytar A, Baltaci G. Acute effects of scapular mobilization in shoulder dysfunction: a double-blind randomized placebo-controlled trial. J Sport Rehabil 2009;18:493-501.

15. Cyriax J. Spinal manipulation and chiropractic. Can Med Assoc J 1972;107:485.

16. Walton DM, Macdermid JC, Nielson W, Teasell RW, Chiasson M, Brown L. Reliability, standard error, and minimum detectable change of clinical pressure pain threshold testing in people with and without acute neck pain. J Orthop Sports Phys Ther 2011;41:644-50.

17. Olson LE, Millar AL, Dunker J, Hicks J, Glanz D. Reliability of a clinical test for deep cervical flexor endurance. J Manipulative Physiol Ther 2006;29:134-8.

18. Vernon H, Mior S. The Neck Disability Index: a study of reliability and validity. J Manipulative Physiol Ther 1991;14:409-15.

19. Aslan E, Karaduman A, Yakut Y, Aras B, Simsek IE, Yaglý N. The cultural adaptation, reliability and validity of neck disability index in patients with neck pain: a Turkish version study. Spine (Phila Pa 1976) 2008;33:362-5.

20. Spielberger CD, Gorsuch RL, Lushene RE. STAI Manual for the State-trait Anxiety Inventory: (Self-evaluation Questionnaire). 1st ed. California: Consulting Psychologists Press; 1970. p. 1-24.

21. Öner N, Le Compte A. Süreksiz durumluluk/sürekli kaygı envanteri el kitabı. İstanbul: Boğaziçi Üniversitesi Yayınları; 1985.

22. Bronfort G, Evans R, Nelson B, Aker PD, Goldsmith CH, Vernon H. A randomized clinical trial of exercise and spinal manipulation for patients with chronic neck pain. Spine (Phila Pa 1976) 2001;26:788-97.

23. Srbely JZ. New trends in the treatment and management of myofascial pain syndrome. Curr Pain Headache Rep 2010;14:346-52.

24. Lin SY, Neoh CA, Huang YT, Wang KY, Ng HF, Shi HY. Educational program for myofascial pain syndrome. J Altern Complement Med 2010;16:633-40.

25. van der Windt DA, van der Heijden GJ, van den Berg SG, ter Riet G, de Winter AF, Bouter LM. Ultrasound therapy for musculoskeletal disorders: a systematic review. Pain 1999;81:257-71.

26. Srbely JZ, Dickey JP. Randomized controlled study of the antinociceptive effect of ultrasound on trigger point sensitivity: novel applications in myofascial therapy? Clin Rehabil 2007;21:411-7. 
27. Unalan H, Majlesi J, Aydin FY, Palamar D. Comparison of high-power pain threshold ultrasound therapy with local injection in the treatment of active myofascial trigger points of the upper trapezius muscle. Arch Phys Med Rehabil 2011;92:657-62.

28. Majlesi J, Unalan H. High-power pain threshold ultrasound technique in the treatment of active myofascial trigger points: a randomized, double-blind, case-control study. Arch Phys Med Rehabil 2004;85:833-6.

29. Koca I, Tutoglu A, Boyaci A, Ucar M, Yagiz E, Isik $\mathrm{M}$, et al. A comparison of the effectiveness of low-, moderate- and high-dose ultrasound therapy applied in the treatment of myofascial pain syndrome. Mod Rheumatol 2014;24:662-6.

30. Ilter L, Dilek B, Batmaz I, Ulu MA, Sariyildiz MA, Nas K, Efficacy of Pulsed and Continuous Therapeutic Ultrasound in Myofascial Pain Syndrome: A Randomized Controlled Study. Am J Phys Med Rehabil 2015;94:547-54.

31. Graff-Radford SB, Reeves JL, Baker RL, Chiu D. Effects of transcutaneous electrical nerve stimulation on myofascial pain and trigger point sensitivity. Pain 1989;37:1-5.

32. Gemmell H, Hilland A. Immediate effect of electric point stimulation (TENS) in treating latent upper trapezius trigger points: a double blind randomised placebo-controlled trial. J Bodyw Mov Ther 2011;15:348-54.

33. Chiu TT, Hui-Chan CW, Chein G. A randomized clinical trial of TENS and exercise for patients with chronic neck pain. Clin Rehabil 2005;19:850-60.
34. Esenyel M, Caglar N, Aldemir T. Treatment of myofascial pain. Am J Phys Med Rehabil 2000;79:48-52.

35. Pikula JR. The effect of spinal manipulative therapy (SMT) on pain reduction and range of motion in patients with acute unilateral neck pain: a pilot study. J Can Chiropr Assoc 1999;43:111.

36. Chiu TW, Wright A. To compare the effects of different rates of application of a cervical mobilisation technique on sympathetic outflow to the upper limb in normal subjects. Man Ther 1996;1:198-203.

37. Di Fabio RP. Manipulation of the cervical spine: risks and benefits. Phys Ther 1999;79:50-65.

38. Hoving JL, Koes BW, de Vet HC, van der Windt DA, Assendelft WJ, van Mameren $\mathrm{H}$, et al. Manual therapy, physical therapy, or continued care by a general practitioner for patients with neck pain. A randomized, controlled trial. Ann Intern Med 2002;136:713-22.

39. Hoving JL, de Vet HC, Koes BW, Mameren Hv, Devillé WL, van der Windt DA, et al. Manual therapy, physical therapy, or continued care by the general practitioner for patients with neck pain: long-term results from a pragmatic randomized clinical trial. Clin J Pain 2006;22:370-7.

40. Lépine JP, Briley M. The epidemiology of pain in depression. Hum Psychopharmacol 2004;19:3-7.

41. Young SB, Aprill C, Braswell J, Ogard WK, Richards JS, McCarthy JP. Psychological factors and domains of neck pain disability. Pain Med 2009;10:310-8. 